\title{
Hot topic: Bovine leukemia virus (BLV)-infected cows with low proviral load are not a source of infection for BLV-free cattle
}

\author{
Marcela A. Juliarena, ${ }^{*}+\ddagger^{1,2}$ Clarisa N. Barrios, ${ }^{*} \ddagger \S^{1}$ M. Carolina Ceriani, ${ }^{*} \ddagger$ and Eduardo N. Esteban ${ }^{*}$ \\ *Laboratorio de Virología del Departamento Sanidad Animal y Medicina Preventiva, and \\ †Departamento de Producción Animal, Centro de Investigación Veterinaria de Tandil, Facultad de Ciencias Veterinarias, \\ Universidad Nacional del Centro de la Provincia de Buenos Aires, Campus Universitario, Tandil B7000, Argentina \\ ¥Consejo Nacional de Investigaciones Científicas y Técnicas, Ciudad Autónoma de Buenos Aires C1425FQB, Argentina \\ $\S$ Centro Biotecnológico La Isleta, Cooperativa Tambera y Agropecuaria Nueva Alpina Ltda, Colonia Alpina G2341, Argentina
}

\section{ABSTRACT}

The bovine leukemia virus (BLV) causes leukemia or lymphoma in cattle. Although most BLV-infected animals do not develop the disease, they maintain the transmission chain of BLV at the herd level. As a feasible approach to control the virus, selection of cattle carrying the BoLA-DRB3*0902 allele has been proposed, as this allele is strongly associated with a BLV infection profile or the low proviral load (LPL) phenotype. To test whether these cattle affect the BLV transmission chain under natural conditions, selected BLV-infected LPL-BoLA-DRB3*0902 heterozygous cows were incorporated into a BLV-negative dairy herd. An average ratio of 5.4 (range 4.17-6.37) BLV-negative cows per BLV-infected cow was maintained during the 20 mo of the experiment, and no BLV-negative cattle became infected. The BLV incidence rate in this herd was thus zero, whereas BLV incidence rates in different local herds varied from 0.06 to 0.17 cases per 100 cattledays. This finding strongly suggests that LPL-BoLADRB $3^{*} 0902$ cattle disrupted the BLV-transmission chain in the study period.

Key words: bovine leukemia virus, bovine leukocyte antigen $D R B 3^{*}$, dairy cow, transmission

\section{Hot Topic}

The bovine leukemia virus (BLV) is the prototype of the genus Deltaretrovirus and is the etiological agent of the enzootic bovine leucosis. Economic losses are high in BLV-infected cows due to BLV-induced leukemia/ lymphoma mortality and reduction of milk production (Ott et al., 2003; Erskine et al., 2012). Because of the high prevalence of BLV, controlling the virus by se-

Received October 2, 2015.

Accepted March 9, 2016.

${ }^{1}$ These authors contributed equally to this work.

${ }^{2}$ Corresponding author: mjuliare@vet.unicen.edu.ar rological detection of BLV-infected cattle and culling from the herd is no longer an economically feasible option. No vaccine or therapeutic procedures to prevent BLV dissemination are available to date.

The natural transmission of BLV occurs by transfer of infected lymphocytes from BLV-infected cattle to BLVfree animals (Ferrer et al., 1975). Blood, secretions, or excretions containing viable lymphocytes transmit the virus (Hopkins et al., 1991). The highest potential of BLV transmission was thought to be associated with dairy farm practices such as repeat use of needles and rectal palpation with a common sleeve (Hopkins and DiGiacomo, 1997). Recently published data (Ooshiro et al., 2013) indicate that blood-sucking insects play a major role in BLV transmission, which is eliminated in the long term when insects are controlled.

Cattle infected with BLV become lifelong virus carriers. The BLV-infected animals have been characterized into 2 profiles or phenotypes of infection: high and low proviral load (HPL and LPL, respectively; Juliarena et al., 2007). This status remains constant after 6 mo of infection. Only a very small number of BLV-infected lymphocytes are found in peripheral blood of LPL animals. The minimum BLV infective dose needed to infect sheep (Burny et al., 1987) is about 926 BLV-infected lymphocytes. Hence, the minimum BLV infective dose in LPL cattle is contained in a volume of blood so great that it is unlikely to be transmitted between animals under normal management conditions in commercial dairy herds.

The BLV-infection phenotypes (LPL and HPL) are associated with polymorphisms of the bovine major histocompatibility complex class II BoLA-DRB 3 gene (Juilarena et al., 2008). One-third of LPL cattle harbor the BoLA-DRB $3^{*} 0902$ allele and so this allele was associated with the LPL phenotype. More than $80 \%$ of cattle that are carriers of the BoLA DRB 3*0902 allele develop LPL when they are naturally or experimentally infected with BLV (Juliarena, 2008; Esteban et al., 2009). 
Animals classed as LPL-BoLA-DRB $3^{*} 0902$ significantly reduce the experimental transmission of BLV to sheep, even when high blood doses are transferred (Juliarena, 2008; Esteban et al., 2009). However, unlike experimental transmission, natural BLV transmission does not involve the transfer of one large dose of blood; instead, there is a long-term, continuous exchange of cells between animals through different routes, different sources, and different doses. Additionally, host susceptibility is dynamic, due to the influence of environmental factors (Collier et al., 2006), and the pressure of milk production frequently reduces resistance. In subtropical areas, caloric stress is important, particularly during the summer season. It is conceivable that heat-stressed animals might be more susceptible to BLV infection.

The selection of cattle using BoLA DRB $3^{*} 0902$ as a marker to control the spread of BLV is an encouraging approach. The effectiveness of this procedure depends on the accuracy of the premise that BLV-infected LPLBoLA-DRB 3*0902 cattle are not a source of infection for BLV-negative cattle in commercial dairy herds. To test this premise, we analyzed the spread of BLV in animals of a dairy herd located in a subtropical region having extreme environmental conditions (hereafter termed the experimental dairy herd). We intervened in this commercial herd in several ways for clear evidence of transmission but maintained normal management practices and production requirements. We also examined the natural spread of BLV in 4 other local commercial herds without intervention.

All animals studied were Holstein cows and heifers. Their BLV-infection status was defined by serological and molecular tests. The cattle were diagnosed by BLVgp51 antibody detection by means of ELISA method 108 (Gutiérrez et al., 2001). The characteristics and validity of this ELISA test have been previously reported (Gutiérrez et al., 2001). We confirmed that the absence of provirus by PCR studies on noninfected animals. The proviral load was determined by the procedure described in Juliarena et al. (2007). The genotype analysis includes $B o L A-D R B 3^{*} 0902$ allele detection by specific PCR (Forletti et al., 2013) and heterozygosis corroboration by RFLP-PCR (van Eijk et al., 1992).

The epidemiological measurements used in this study have been previously described (Toft et al., 2003). Prevalence was determined by dividing the number of BLV-infected cattle in a population at the beginning of the study by the total cattle population and was expressed per 100 cattle. Incidence was estimated as the number of new BLV-infected animals within the study period divided by the size of the population initially at risk (BLV-free cattle) and was expressed per 100 cattle. Incidence rate was estimated as the number of new BLV-infected animals in the study period, as determined by serology or PCR testing, divided by the total follow-up in days and was expressed as cases per 100 cattle-days. The contact rate was calculated as the number of BLV-free cattle divided by the number of BLV-infected cattle in the same population.

Our first intervention was to apply a long and costly BLV eradication program on a selected dairy herd. This program involved culling BLV-positive cattle and replacing them with BLV-negative cattle taken from other dairy farms. The herd was declared BLV-free when no newly infected cows appeared 3 mo after the last negative serological testing. To meet the expansion of this herd according to production requirements, BLV-negative pregnant heifers were selected and isolated in different pastures.

Next, BLV-infected LPL-BoLA-DRB $3^{*} 0902$ cattle in heterozygosis with other alleles (alleles not associated with BLV-infection phenotype; Juliarena et al., 2008) were selected and introduced into the BLV-free herd (the experimental dairy herd). All cattle of the experimental dairy herd were lactating cows. Besides the experimental herd, we also observed and registered the prevalence, incidence, and incidence rate in other commercial, nonexperimental (without intervention) herds belonging to the same dairy cooperative.

Nonexperimental herds were (1) a pre-birth herd: pregnant heifers ( $>5$ mo of pregnancy) plus dry cows; (2) post-service heifers: post-service and pregnant heifers ( $<5$ mo of pregnancy); (3) commercial dairy herd 1 , consisting of lactating cows; and (4) commercial dairy herd 2, consisting of lactating cows. The observational period for the nonexperimental herds depended on animal movement or replacement, which was carried out according to production needs. The distribution of infection phenotypes of the BLV-infected animals in every nonexperimental herd was at random (Table 1 ).

All 5 herds were located in a subtropical region belonging to the Departamento Rivadavia (southeast region of the Santiago del Estero province, Argentina) and were managed by a single group of professionals. Management practices (such as milking twice a day, feeding, drinking) and veterinary practices (such as vaccinations, rectal palpations, blood sampling, and AI) were performed as for any commercial dairy herd in the region but, for the experimental herd, strictly avoiding any contact with external cattle. There were no insect control programs, and the animals were exposed to the bites of a high-density and varied population of hematophagous insects that continuously fed on the animals during the warmest seasons.

Management practices present a risk of transferring cells between animals. Cows subjected to mechanical milking show a higher prevalence of infection by BLV than cows subjected to manual milking (Fernandes et 
al., 2009). Nevertheless, BLV transmission through these practices has not been directly proven. Major known risk factors for BLV transmission in all 5 herds in this work were (1) rectal palpation using common sleeves; (2) vaccinations or intravenous injection using common needles; and (3) high density of blood-sucking insects, which was the most insidious risk factor.

Bleedings and AI were done using a single device per animal. It is unlikely that sperm would transmit BLV when AI is used (Monke, 1986). The very small number of BLV-infected lymphocytes that can be present in sperm would be unlikely to survive the procedure of freezing and thawing the diluted sperm. Thus, neither of these 2 factors should represent a risk for BLV transmission in the current study.

In the experimental dairy herd, BLV-free and BLVinfected LPL-BoLA-DRB $3^{*} 0902$ animals had 20 mo of contact. This period included 2 summers during which BLV-infected and uninfected cattle were exposed to heat stress. As is usual in any commercial dairy herd, the cattle population was dynamic and necessary replacements were made according to production needs and milk production requirements, which were within expected parameters in the region. Nevertheless, only previously characterized animals were introduced to the experimental herd. The contact ratio for BLV-free cattle:BLV-infected LPL-BoLA-DRB3*0902 cattle ranged between 4.17 and 6.37 , and the monthly average was 5.4 (Table 1 ).

In the nonexperimental herds, animals were in contact for periods ranging from 2 to 12 mo. The contact rate of BLV-free cattle:BLV-infected varied widely among the nonexperimental herds, from 0.4 to 13.1 (Table 1). Despite the shorter period of contact, newly
BLV-infected cattle were found in all nonexperimental herds (Table 2). The incidence rates observed in different herds were between 0.06 and 0.17 cases per 100 cattle-days. In contrast, no new BLV-infected animals were detected by serological and PCR testing among BLV-free cattle in the experimental herd after a much longer period of contact under the same environmental conditions and management practices, and, as a corollary, the incidence rate was zero. The results indicate that LPL-BoLA-DRB $3^{*} 0902$ cattle do indeed disrupt the BLV transmission chain, and selection of cattle carrying this allele represents a promising approach to control the virus.

\section{ACKNOWLEDGMENTS}

This work was supported by the Fondo Nacional Ciencia y Técnica [PID 2008-024; Ciudad Autónoma de Buenos Aires], the Secretaria de Ciencia, Técnica y Gestión Productiva de la Provincia, Santiago del Estero, and the Cooperativa Tambera Nueva Alpina (COTANA) Colonia Alpina, Argentina. We thank Marcelo Uberti for providing the use of his laboratory, equipment, and personal skills for cattle blood processing (Laboratorio Laredive, Ceres, Argentina). We also thank the members and staff of dairy cooperative (COTANA), especially the manager Angel Lopez, for his strong support to this project and Jorge Trossero and his team of veterinarians: Nicolas Giaccone, Patricio Renk, Cristian Jorge, and Matías Leiva for their invaluable support maintaining the health of the experimental livestock. We thank Patricia Bani and Norma Rodriguez for their technical and administrative assistance (Laboratorio de Virología, Facultad de

Table 1. Distribution of cattle per herd according to bovine leukemia virus (BLV) infection status ${ }^{1}$

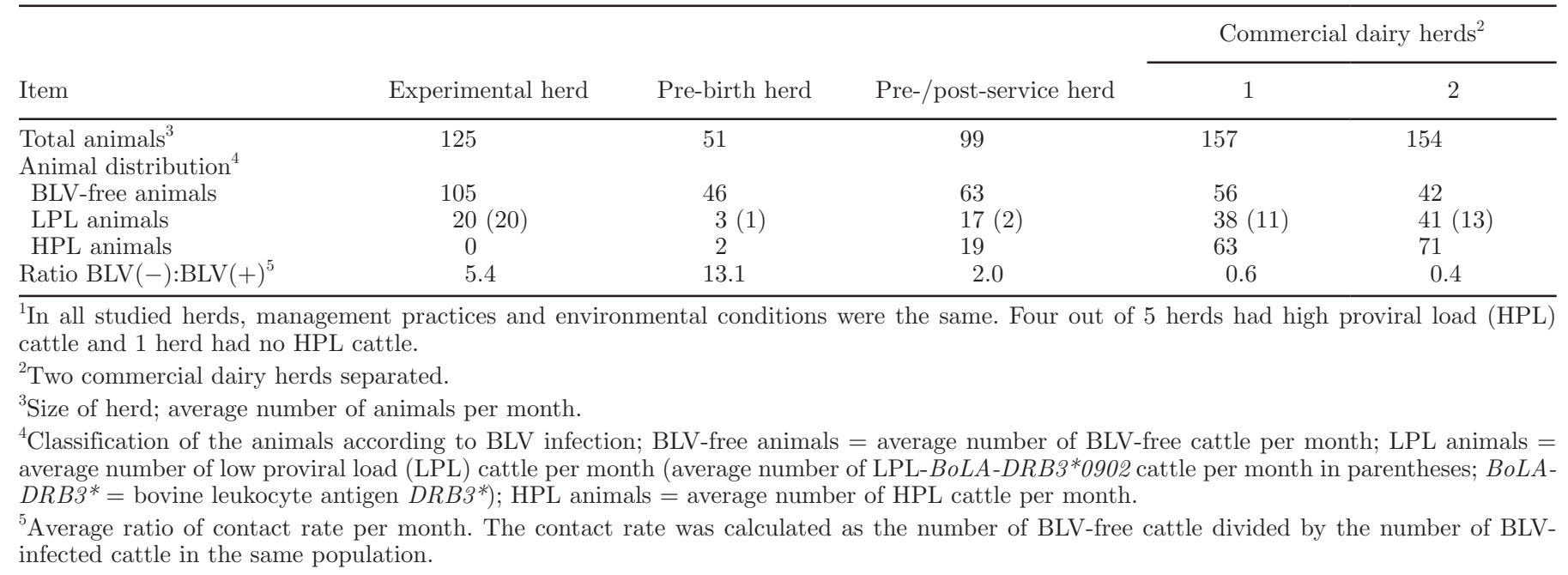


Table 2. Epidemiological measurements in the different dairy herds observed ${ }^{1}$

\begin{tabular}{|c|c|c|c|c|c|}
\hline \multirow[b]{2}{*}{ Item } & \multirow{2}{*}{$\begin{array}{l}\text { Experimental dairy } \\
\text { farm }\end{array}$} & \multirow[b]{2}{*}{ Pre-birth herd } & \multirow[b]{2}{*}{ Pre-/post-service herd } & \multicolumn{2}{|c|}{$\begin{array}{c}\text { Commercial dairy } \\
\text { farms }^{2}\end{array}$} \\
\hline & & & & 1 & 2 \\
\hline Period of observation, mo & 20 & 2 & 5 & 12 & 12 \\
\hline New BLV-infected animals & 0 & 2 & 6 & 26 & 20 \\
\hline Incidence, \% & 0 & 4.3 & 10.3 & 46.4 & 47.6 \\
\hline
\end{tabular}

${ }^{1}$ Cattle were observed during different periods. Only the herd lacking high proviral load (HPL) cattle lacked bovine leukemia virus (BLV) transmission.

${ }^{2}$ Two commercial dairy herds separated.

${ }^{3}$ Prevalence at the beginning of study.

${ }^{4}$ The incidence rate was estimated as the number of new BLV-infected animals in the study period, as determined by serology or PCR testing, divided by the total follow-up in days.

Ciencias Veterinarias, Universidad Nacional del Centro de la Provincia de Buenos Aires, Tandil, Argentina).

\section{REFERENCES}

Burny, A., Y. Cleuter, R. Kettmann, M. Mammerickx, G. Marbaix, D. Portetelle, A. Van den Broeke, L. Willems, and R. Thomas. 1987. Bovine leukaemia: Facts and hypotheses derived from the study of an infectious cancer. Cancer Surv. 6:139-159. (Review).

Collier, R. J., G. E. Dahl, and M. J. VanBaale. 2006. Major advances associated with environmental effects on dairy cattle. J. Dairy Sci. 89:1244-1253. (Review).

Erskine, R. J., P. C. Bartlett, T. M. Byrem, C. L. Render, C. Febvay, and J. T. Houseman. 2012. Association between bovine leukemia virus, production, and population age in Michigan dairy herds. J. Dairy Sci. 95:727-734.

Esteban, E. N., M. Poli, B. Poiesz, C. Ceriani, S. Dube, S. Gutierrez, G. Dolcini, R. Gagliardi, S. Perez, C. Lützelschwab, L. Feldman, and M. A. Juliarena. 2009. Bovine leukemia virus (BLV), proposed control and eradication programs by marker assisted breeding of genetically resistant cattle. Chapter 4 in Animal Genetics. L. J. Rechi, ed. Nova Science Publishers, New York, NY.

Fernandes, C. H. C., L. E. H. de Melo, T. G. da S. Tenório, E. I. Mendes, A. C. de C. Fernandes, T. R. R. Ramalho, P. A. Moura Sobrinho, and R. A. Mota. 2009. Soroprevalência e fatores de risco da infecção pelo Vírus da Leucose dos Bovinos em rebanhos leiteiros da região norte do estado do Tocantins, Brasil. Arq. Inst. Biol. (Sao Paulo) 76:327-334.

Ferrer, J. F., C. E. Piper, D. A. Abt, R. R. Marshak, and D. M. Bhatt. 1975. Natural mode of transmission of the bovine C type leukemia virus (BLV). Bibl. Haematol. 43:235-237.

Forletti, A., M. A. Juliarena, C. Ceriani, A. F. Amadio, E. Esteban, and S. E. Gutiérrez. 2013. Identification of cattle carrying alleles associated with resistance and susceptibility to the Bovine Leukemia Virus progression by real-time PCR. Res. Vet. Sci. 95:991-995.

Gutiérrez, S. E., G. L. Dolcini, G. H. Arroyo, C. Rodriguez Dubra, J. F. Ferrer, and E. N. Esteban. 2001. Development and evaluation of a highly sensitive and specific blocking enzyme-linked immunosorbent assay and polymerase chain reaction assay for diagnosis of bovine leukemia virus infection in cattle. Am. J. Vet. Res. 62:1571-1577.

Hopkins, S. G., and R. F. DiGiacomo. 1997. Natural transmission of bovine leukemia virus in dairy and beef cattle. Vet. Clin. North Am. Food Anim. Pract. 13:107-128. (Review).

Hopkins, S. G., R. F. DiGiacomo, J. F. Evermann, J. D. Christensen, D. P. Deitelhoff, and W. D. Mickelsen. 1991. Rectal palpation and transmission of bovine leukemia virus in dairy cattle. J. Am. Vet. Med. Assoc. 199:1035-1038.

Juliarena, M. A. 2008. Aportes al estudio del rol del virus y del hospedador en el perfil de infección causados por el virus de la leucosis bovina. Doctoral Thesis. Univ. Nacional del Centro de la Provincia de Buenos Aires, Argentina.

Juliarena, M. A., S. E. Gutierrez, and C. Ceriani. 2007. Determination of proviral load in bovine leukemia virus-infected cattle with and without lymphocytosis. Am. J. Vet. Res. 68:1220-1225.

Juliarena, M. A., M. Poli, L. Sala, C. Ceriani, S. Gutierrez, G. Dolcini, E. M. Rodríguez, B. Mariño, C. Rodríguez-Dubra, and E. N. Esteban. 2008. Association of BLV infection profiles with alleles of the BoLA-DRB3.2 gene. Anim. Genet. 39:432-438.

Monke, D. R. 1986. Noninfectivity of semen from bulls infected with bovine leukosis virus. J. Am. Vet. Med. Assoc. 188:823-826.

Ooshiro, M., S. Konnai, Y. Katagiri, M. Afuso, N. Arakaki, O. Tsuha, S. Murata, and K. Ohashi. 2013. Horizontal transmission of bovine leukemia virus from lymphocytotic cattle, and beneficial effects of insect vector control. Vet. Rec. 173:527-528.

Ott, S. L., R. Johnson, and S. J. Wells. 2003. Association between bovine-leukosis virus seroprevalence and herd-level productivity on US dairy farms. Prev. Vet. Med. 61:249-262.

Toft, N., J. F. Agger, H. Houe, and J. Bruun. 2003. Measures of disease frequency. Pages 79-96 in Veterinary Epidemiology. H. Houe, A. K. Ersboll and N. Toft, ed. The Royal Veterinary and Agricultural University, Frederiksberg, Denmark.

van Eijk, M. J., J. A. Stewart-Haynes, and H. A. Lewin. 1992. Extensive polymorphism of the BoLA-DRB3 gene distinguished by PCR-RFLP. Anim. Genet. 23:483-496. 